\title{
THE IMPACT OF MANAGEMENT QUALITY ON FIRMS' INNOVATION AND PRODUCTIVITY IN RUSSIA
}

\author{
Mariev, O., Davidson, N., Nagieva, K.
}

Oleg Mariev / Ural Federal University, Graduate School of Economics and Management, Mira Street, 19, Ekaterinburg, Russia. Email: o.s.mariev@urfu.ru.

Natalia Davidson / Ural Federal University, Graduate School of Economics and Management, Mira Street, 19, Ekaterinburg, Russia.Email: natalya.davidson@gmail.com.

Karina Nagieva / Ural Federal University, Graduate School of Economics and Management, Mira Street, 19, Ekaterinburg, Russia.Email: karina.nagieva74a@gmail.com.

\begin{abstract}
Innovations are among the most important drivers of firms' productivity improvement. Newly introduced products and processes, as well as organizational and marketing practices, are important for firms' performance and for countries' prosperity. In this paper, we analyze how management processes influence firms' innovation and performance based on Russian data. Our main research question is how the quality of management affects innovative results and thereby, productivity. We employ a survey of enterprise activities, and business climate BEEPS covering the period 2012-2014 and including 1564 firms. Based on the existing literature, we create a framework to study the impact of various factors on firms' innovation and productivity. We study both internal factors such as a firm's quality of management and external factors such as innovation climate in the region and availability of private and public financing. A model applied in our research is a well-known CDM model containing three stages. This model makes it possible to analyze expenditures for research and development, implementation of innovations, and then its impact on the firm's performance. Estimation results demonstrate that enterprises benefit from innovations. The same time, our research shows the importance of management quality in the firms' innovative activities among the other internal and external factors affecting innovations. Results can be applied by the enterprises interested in innovations and by policymakers involved in facilitating innovations at the regional and country level.

Implications for Central European audience: A version of a well developed CDM model is used, which makes results reliable; the model can be further applied for the analysis of various economies, including the countries of Central Europe. Our research sheds light on the determinants of innovation activity at all its stages, creating a background for analysis and development of economic policy. A key implication is that management quality deserves attention along with other factors affecting firms' innovation and productivity. The research is based on firm-level BEEPS data for Russia, making the possible comparison with the other countries covered by BEEPS survey.
\end{abstract}

Keywords: R\&D; innovations; productivity; firms; management practices; human capital; economic policy

JEL Classification: $031, \mathrm{O} 32, \mathrm{O} 38$ 


\section{Introduction}

Innovations are among the most important drivers of firms' productivity improvement (Bartz et al., 2016). In other words, new products, processes, organizational and marketing innovations are important for firms' competitiveness and thereby for the economic growth of countries. The impact of innovation on productivity tends to be positive and significant (Crépon et al., 1998; Mohnen \& Hall, 2013). Therefore, policymakers usually proclaim fostering innovations among their goals, and the ability to innovate is essential for firms' success. In this light, it is important to understand which processes need to take place at the firm and regional level so that innovations could develop. Concerning firm-level factors, the aspect that deserves more attention is the managers' role in the innovation process. Indeed, there is evidence that management practices are essential for enterprise performance, including innovations and productivity (Bartz et al., 2016).

Our aim is to analyze the role of management processes in firms' innovation and performance based on Russian data. Our main research question is how the quality of management affects innovative results and thereby, productivity. We assume that quality of management depends on the top manager's experience (measured in years) and on the new organizational or management practices or structures implemented during the recent three years (reflected in data as a dummy-variable). To study the issue of innovations in Russia, a survey of enterprise activities and business climate BEEPS covering the period 2012-2014 is used. The influence of management on firms' innovation and productivity is analyzed based on the CDM model containing three stages. This model makes it possible to analyze expenditures for research and development, implementation of innovations, and then its impact on a firm's performance. A number of firm-level variables and indicators characterizing external environment are considered, for example, human capital and business climate. Regional level data is used to account for regional innovation development.

Firms' heterogeneity in terms of their productivity and other features has been addressed in the literature. Innovation activity has been put forward by the authors of various theories as an essential reason behind the differences among firms (Hashi \& Stojcic, 2012). Schumpeter (1934) has suggested a theory explaining differentiation between firms by their innovation activity. According to him, the motivation for innovative activities is the entrepreneur's desire to change the existing organizational structures through the development of new goods, new production methods, by looking for new customers and suppliers. Therefore 'creative destruction' takes place in the market economy, where more innovative and efficient firms prosper, while less innovative ones exit the market. Within the evolutionary and resource-based theory, innovation is interpreted in the context of a firm meeting the requirements of its environment (Nelson \& Winter, 1982).

Further, the role of knowledge in enterprise performance and countries' economic success has been addressed by researchers. The reason is that economic growth based on an increase in the number of resources is characterized by diminishing returns and is not sustainable (Marotta et al., 2007). This attracted attention to human capital and innovations as drivers of long-term economic growth. The theoretical background has been developed: exogenous (Solow, 1957, etc.) and endogenous (Romer, 1990; Grossman \& Helpman, 1994 , etc.) growth models. Specifically, the idea behind endogenous growth models is that knowledge generates both the direct effects for a firm and spillovers from which the other 
firms in the economic benefit. Therefore aggregate production function demonstrates increasing returns to scale, making possible long-term economic growth (Marotta et al., 2007). We are interested in the quality of management, as it makes possible efficient use of the available technologies and can facilitate the creation of new knowledge. Along with management quality, we include variables reflecting the quality of human capital, namely the level of workers' qualification and training of personnel.

The activities both of enterprises and Government contribute to innovations. Enterprises create their own ideas and use findings of other organizations (enterprises, universities, research centres). Public authorities can substantially support the development of basic and applied research as well as create a transparent institutional environment favourable for inventions and innovations. Besides, public policy can support firm-level innovation (Potluka \& Dvouletý, 2018). Griliches (1986) analyzed data on about 1.000 largest manufacturing firms in the USA for the years 1957-77 based on a standard production function augmented by R\&D "capital" and "mix" variables. He found that throughout the whole period of observation, R\&D has steadily contributed to productivity growth. Moreover, he found a substantial contribution to basic research. Another finding was that R\&D financed by the Government contributed less to productivity growth than privately financed R\&D. Based on these findings, we create a framework to study the impact both of firm-level factors (quality of management being our focus) and of external factors such as innovation climate in the region.

In the next part, we provide an overview of research devoted to innovations. Then data and econometric model are presented. Afterwards, results are discussed, and the conclusion follows.

\section{Background}

Determinants of innovations, as well as the influence of innovations on enterprise performance, have been covered in numerous papers. Authors usually apply either a CDM model (Crépon et al., 1998) and its modifications or probit model and tend to demonstrate positive effects of R\&D and innovations on enterprise performance (Marotta et al., 2007; Cirera, 2015). Koudelková (2014) found a positive effect of innovations on Czech SMEs' growth. Therefore she suggests the Government focuses on innovation in order to enhance economic development. Besides, there is evidence in the literature that probability of innovating depends on the firms' ability to absorb new knowledge, as well as on human capital and cooperation (Marotta et al., 2007).

In our paper, we employ a model by Crépon et al. (1998) linking research and development, innovations and enterprise performance in order to follow the process of creating innovations and their actual impact on enterprise performance. CDM model is used in numerous papers, while a number of equations and measurement of innovations can be different. Among the ways to measure innovations are innovative sales per employee (Lööf et al., 2003; Janz et al., 2004), the probability that a product, process or another type of innovation will take place (Hall et al., 2008; Duguet, 2006) and firm's external reward for its new product (Teplykh, 2018).

In this paper, we focus our attention on the quality of management. Among seminal works is research by Porter (1998) concerning companies' competitive strategies, where innovation plays a crucial role. In order to stay competitive firms need to be able to produce 
at a lower cost, offer customers new products and services, and find and dominate profitable niches in the market.

Bartz et al. (2016) study the impact of innovations and practices of management on the firms' performance in emerging countries. They employ a CDM model containing three stages and firm-level survey covering thirty Eastern European and Central Asian countries for the years 2011-2014. To distinguish between quality of management processes and innovations, the authors emphasize that not all improvements in management practices can be classified as organizational innovations. Furthermore, they consider not improvements in management processes, but their quality at the moment. They study the impact of management practices directly on innovations and on productivity, as well as an indirect impact of management practices through innovations on productivity.

The results show that both innovations and management practices substantially influence productivity in developing countries, while management practices are on average, more important for these countries than innovations. The authors find differences in conditions for the firms associated with infrastructure, availability of financing and other opportunities accessible in large cities, but not in smaller towns. They find that in lower-income economies, management practices substantially influence productivity, and for higherincome countries, innovations are relatively more important. The authors link this result to a less favourable business environment in the lower-income countries and suggest to these countries to improve the quality of management practices before getting involved in innovation. Besides, they study industries with various technological intensities and find the relative importance of innovations for productivity in industries with higher technological intensities, and relative importance of management practices in industries with lower technological intensities. In our paper, we study the impact of management practices on innovations and then estimate an indirect impact of management practices through innovations on productivity. We consider the quality of management processes at the moment and their improvement over time.

Marotta et al. (2007) study the factors influencing innovations in Chile and Columbia based on a sample of manufacturing firms from innovation surveys and employing a probit model. They reveal that cooperation with universities and research centres increases the probability of innovations. For Columbian firms having cooperation with research centres, the increase was found to be especially high. The authors find that firms with bettereducated employees and managers are more likely to innovate and suggest to stimulate human capital improvement at the enterprises, as well as cooperation between firms and universities (Marotta et al., 2007). We extend this idea to study the impact of management quality associated with managers' human capital on innovations and productivity of the Russian firms, taking into account workers' human capital and cooperation as well.

It is worth taking into account that apart from the firm-level factors, such as management quality, innovations and productivity are influenced by the external factors. Dabla-Norris et al. (2012) study the influence of innovation on firm's total sales per employee. Innovations are represented by new products or technologies, or by an aggregate indicator of innovation activities. The authors consider the impact of financial services on firms' activities based on the World Bank Enterprise Survey (WBES) covering 63 developed and developing countries for the years 2005 and 2007. Dabla-Norris et al. (2012) found that innovations played an essential role in the firms' performance. Moreover, they found that 
firms benefited the most from innovation in the countries where the financial sector was well-developed. To continue the topic of access to finance, Prędkiewicz (2017) studies the connection between access to financing and innovations performed by the firms. He concludes that smaller firms have relatively more difficulties with access to financing, and innovative companies have similar problems as well. The author, therefore, makes a policy recommendation to provide smaller and innovative firms with subsidies.

Further, Dvouletý \& Blažková (2019) evaluate the impact of investment subsidies on the firms belonging to the food industry in the Czech Republic. They study a group of firms that received the subsidies and a group of firms that did not have such support. The authors found that the subsidy positively affected firms' labour productivity. Public policy can probably facilitate firms' investment in R\&D and innovation activity, while the results in the literature concerning the impact of public policy are contradictory (Potluka \& Dvouletý, 2018). Potluka \& Dvouletý (2018) study the impact of the European Regional and Development Fund program on the companies' employment, sales and profit. Grants within this program could be used by firms for various types of innovations (product, process, organizational, marketing). The authors found that innovation assistance positively affected enterprise performance. However, they suggest to treat the results cautiously and to continue the practice of evaluating public policy programs for Central and Eastern European countries using a rigorous approach.

Cirera (2015) studies innovations and productivity in the Kenyan economy based on CDM model and data on firms in different industries. He emphasizes that the competitiveness of Kenyan enterprises on the international level as well as employment opportunities for workers depend on the firms' ability to increase productivity. He explains that this is the way to increase incomes in the country and to achieve shared prosperity. According to Cirera (2015), investments into knowledge formation and innovations are fundamental to this process. The author concludes that firms in Kenya invest relatively intensively into research and development; however, it does not result in innovation and productivity growth as much as it could. The author explains this by lack of investment into knowledge input, lack of financing, over-reliance on internal sources for innovations and inadequate educational level of workers. Besides, Cirera (2015) reveals a positive impact of innovations on employment opportunities for skilled labour and claims that unskilled labour also seems to benefit from innovations. We use a similar approach within the framework of the CDM model to disentangle the innovative process of the firms in Russia.

Hashi \& Stojcic (2012) raise an issue that productivity of the European firms lags behind that of the US and Japanese firms, while innovations are known to be the principal driving force of firms' productivity. They employ Community Innovation Survey (CIS 6) 2006 that provides enterprise-level data and use the CDM model to study the impact of innovative activity on enterprise performance in Europe. The results demonstrate a positive impact of innovations on enterprise performance. Meanwhile, decisions to innovate are affected by previously accumulated knowledge and by cooperation with various stakeholders. Size of the firms is found to affect positively their opportunities to innovate and negatively their innovation output. The authors revealed that concentration of firms, involvement in export, subsidies and information externalities are favourable for innovations. They also found that firms from new EU members are relatively less involved in innovation activity compared to the firms from Western European countries. The authors conclude that innovations are 
important for convergence between older EU members and new members and candidate countries. Russian firms also have a need to improve their productivity; therefore, we continue an approach of the authors to follow the connection between enterprise innovations and performance.

Bozic \& Botric (2011) study economies in transition using Business Environment and Enterprise Performance Survey 2009 and applying the probit model. They refer to the findings of research on transition countries, reflecting that innovation activities there are rather subdued, while innovation is known to be essential for economic growth. Their results show that firms' propensity to innovate is affected by subsidies, by demand factors and international competition, country-level factors, taxation, human capital and size of an enterprise. By taking these factors into consideration, economic policy can help improve innovation activities in transition countries.

Another method that can be employed to analyze enterprise performance was developed by Petrin et al. (2004). It is based on Cobb-Douglas production function and allows analyzing the impact of a number of factors on enterprise value added or revenue, taking into account exogenous shocks that occur in the economy. Zhukov et al. (2017) based on data for Russia and using this method along with fixed and random effects methods find that an increase in advanced production technologies used in a region positively affects the firms' revenues. Therefore in the framework of economic policy, it is important to create an environment favourable for the firms' innovations.

Zemtsov et al. (2017) perform a regional level analysis of innovations in Russia. They claim that in the 2000s expenditures on innovation increased in Russia. However, regions differ substantially in terms of innovation outcomes. Nowadays, innovations are a priority in Russia. Therefore factors influencing regional innovation should be understood. Increasing spending on $R \& D$ is among the factors that were found in the literature to be essential for growth in regional innovations. Zemtsov et al. (2017) find that human capital associated with people having higher education and living in large cities has the greatest impact on the number of patents. The authors also found that buying equipment and spending on basic research are important for innovations in the Russian regions. It is noted in the paper that there is a flow of human capital towards the most developed regions. It happens due to the presence of innovation centres, and periphery in Russia and such flow of highly qualified personnel further weakens the periphery regions.

Literature review shows that the CDM model provides a coherent picture of the innovative process, following the link between firms' investment in R\&D, innovative output and firm's productivity. Research also shows that innovation tends to positively influence firms' productivity, and at the same time innovation is underdeveloped in the transition economies. Besides, researchers point out that it is worth considering innovation activities along with management quality. In the next section, we explain our approach to analyzing the impact of management quality on innovation and productivity and present data employed in our research.

\section{Data and Methods}

Our study is based on data for Russian firms from BEEPS - Business Environment and Enterprise Performance Survey, conducted by the World Bank and the European Bank for 
Reconstruction and Development and covering the period 2012-2014. The survey contains firm-level indicators and information on the perception of the business environment. Firmlevel data contains information on performance, employees and managers, as well as on innovation activity. The data is collected from the managers and therefore brings first-hand information about the firms' internal and external environment. The final sample consists of 1564 manufacturing enterprises. It covers 37 Russian regions. Distribution of enterprises by industries in Figure 1 shows that the largest number of firms are represented by such industries as Furniture, Wood, Precision instruments, IT, Chemicals, Non-metallic mineral products, Publishing, Electronics, Plastics \& Rubber, Food, Fabricated metal products, Machinery and equipment.

Figure 1 | Distribution of firms by industries, in \%

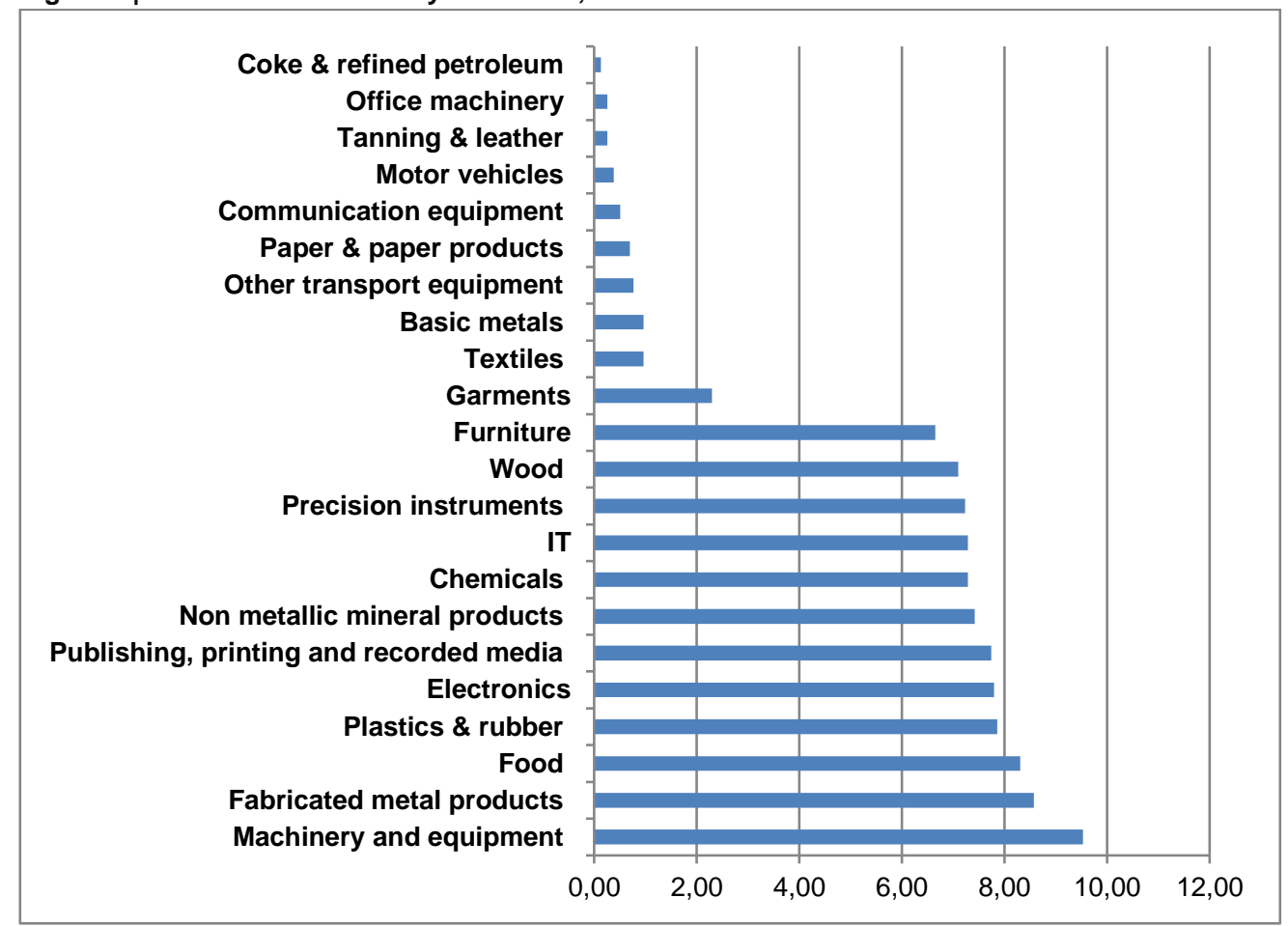

Source: authors' elaboration based on BEEPS 2012-2014

In this paper, we apply a modified CDM model. The sequence of stages in the model allows us to cover the innovation process as a whole and to take into account various factors at each stage.

The model contains three steps. Firstly, enterprises make decisions concerning R\&D investment. Dependent variable at the first stage is a dummy variable, equal to 1 in case of investment that took place over three years and 0 otherwise. A probit model is applied at this stage. 
Based on previous literature (Bozic \& Botric, 2011; Cirera, 2015) we have identified the following groups of independent variables for the first stage of the model:

- Determinants associated with competition and import. All these determinants stimulate firm-level innovations. Indeed, in order to stay competitive firms need to innovate, while an import is associated with spillovers from foreign firms' knowledge and technologies.

- Determinants arising from business climate, namely, from government support in the form of subsidies and obstacles associated with high tax rates, business licensing and permits ${ }^{1}$ and inadequacy of the workers' specialization. Our hypotheses are that subsidies are favourable for innovations, while obstacles associated with business environment decrease innovation activity.

In BEEPS these indicators are measured as ordinal variables: no obstacles - 0, a minor obstacle - 1, a moderate one - 2 , the main barrier - 3 and a very serious barrier - 4. In accordance with Bozic \& Botric (2011) we converted these indicators to dummy variables, equal to 1 if for the firm's external factors were major or very serious obstacles, and 0 otherwise.

- Determinants associated with regional level of innovations. Regional innovation development index is used to account for an innovative environment in a region. It is assumed that a high level of innovations carried out in a region will stimulate an enterprise to innovate.

- Enterprise level factors: age, size and belonging to a larger enterprise. It is assumed that large enterprises have stronger propensity to innovate due to better opportunities available to them. Another hypothesis is that startups and young enterprises are more likely to be innovatively active. Finally, one can assume that if an enterprise is a part of a group of enterprises, it has additional resources of various kinds to get involved in innovations.

As it can be seen from Table 1, on average, almost 19\% of firms performed research and development during the recent three years, and $13 \%$ of the firms are large firms, while the majority of enterprises in the sample are SMEs. Average firms' age is about 13 years, and the oldest firm was established 174 years ago.

On average, firms have 33 direct competitors. Almost $8 \%$ of the firms belong to a large association, and $8 \%$ of firms received subsidies from various sources. In terms of the barriers, on average, about $61 \%$ of firms experience difficulties with tax rates, $28 \%$ - with a mismatch of the educational level with the workers' skills, and $13 \%$ - with business licensing and permits. Only $8 \%$ of firms are engaged in import. The largest index of innovation development of Russian regions is recorded in Moscow with a value of 0.585 .

\footnotetext{
${ }^{1}$ Permission to carry out a certain type of activity.
} 
Table 1 | Variables: the first stage of the CDM model

\begin{tabular}{llll}
\hline Variable & Mean & Minimum & Maximum \\
\hline R\&D investments over 3 years, dummy variable & 0.187 & 0 & 1 \\
\hline $\begin{array}{l}\text { Size of the firm, dummy variable (1 - large firm, more } \\
\text { than 100 people) }\end{array}$ & 0.129 & 0 & 1 \\
\hline Age, number of years & 12.819 & 0 & 174 \\
\hline Competition, number of competitors & 33.297 & 0 & 100 \\
\hline Part of a larger enterprise & 0.077 & 0 & 1 \\
\hline Subsidies & 0.076 & 0 & 1 \\
\hline Taxes & 0.606 & 0 & 1 \\
\hline Inadequacy of the employees' qualification & 0.283 & 0 & 1 \\
\hline Import & 0.083 & 0 & 1 \\
\hline Business licensing and permits & 0.129 & 0 & 1 \\
\hline Regional innovation development index & 0.421 & 0.287 & 0.585 \\
\hline Soure aut & & & \\
\hline
\end{tabular}

Source: authors' elaboration based on BEEPS 2012-2014

The next step of the model implies estimating the impact of the predicted probability of investing in research and development over three years on the innovative result (logarithm of innovative sales, i.e. sales of new products). This indicator reflects the commercialization of new products. The choice of the dependent variable is in line with the Oslo Manual defining innovation the following way: "...the implementation of a new or significantly improved product (good or service), or process, a new marketing method, or a new organizational method in business practices, workplace organization or external relations" (Oslo Manual, 2005). OLS method is used.

We incorporate into the model the indicator of human capital at the firm level measured as a dummy variable reflecting personnel training. We assume that enhancing the skills of the workforce will facilitate innovations. Along with these factors, variables that account for the cooperation of an enterprise with different stakeholders are introduced, including licensing ${ }^{2}$. It is assumed that cooperation enhances innovations compared to relying only on the enterprise's own ideas and resources.

At this stage, assessment of the contribution of management to the innovative success of the company is of particular interest (Bartz et al., 2016; Marotta et al., 2007). For this, we use two indicators of management in the equation of innovation. One of the management indicators is the top manager's work experience in a sector (years), and the other is a dummy variable, equal to 1 if the company introduced new organizational/management practices or structures during past three years, and 0 otherwise. We believe that these indicators are important for promoting innovation, as managers determine a development strategy, coordinate and organize the work of all departments.

At stage three, the innovative result predicted from the second stage is used to evaluate its impact on productivity. At this step, we apply an extended Cobb-Douglas production function:

$$
\log y_{i j}=\delta_{0}+(1-\alpha-\beta) \log h_{i j}+\alpha \log k_{i j}+\beta \log l_{i j}+\varepsilon_{i j},
$$

${ }^{2}$ Permission for a certain fee for the use of inventions, industrial designs, trademarks. 
where $y, h, k, I$ - logarithms of revenue, innovative sales, capital and labour costs per worker.

We measure labour productivity as revenue per worker. In order to reflect the firm's size, innovative sales, capital and labour costs were also divided by the number of employees. Capital costs are measured as spending on purchases of machinery, vehicles and equipment. This step is estimated using OLS method.

Below are variables used further in CDM model (Table 2).

Table 2 | Variables: the second and third stages of CDM model

\begin{tabular}{llll}
\hline Variable & Mean & Minimum & Maximum \\
\hline Innovative sales, thousands rubles & 89900 & 0 & 9750000 \\
\hline Top manager's experience in the sector (years) & 15.72 & 1 & 60 \\
\hline $\begin{array}{l}\text { New organizational/managment practices } \\
\text { structures introduced during past 3 years }\end{array}$ & 0.288 & 0 & 1 \\
\hline Licensing & 0.012 & 0 & 1 \\
\hline Cooperation with domestic suppliers & 0.033 & 0 & 1 \\
\hline Cooperation with foreign suppliers & 0.012 & 0 & 1 \\
\hline Cooperation with domestic consumers & 0.019 & 0 & 1 \\
\hline Cooperation with foreign consumers & 0.003 & 0 & 1 \\
\hline $\begin{array}{l}\text { Cooperation with universities or research } \\
\text { institutions }\end{array}$ & 0.011 & 0 & 1 \\
\hline Training of personnel & & & \\
\hline Revenue, thousands rubles & 0.446 & 0 & 1 \\
\hline Capital costs, thousands rubles & 433000 & 0 & 80000000 \\
\hline Labor costs, thousands rubles & 28300 & 0 & 9000000 \\
\hline
\end{tabular}

Source: authors' elaboration based on BEEPS 2012-2014

The table above shows that the average innovative sales of firms amounted to 89.900 thousand rubles, while the average revenue was 433.000 thousand rubles, the average capital cost was 28.300 thousand rubles, and the average labour costs were 35.400 thousand rubles.

At the same time, the average values of cooperation reflected as dummy variables, where 1 is cooperation and $0-$ no cooperation, are generally small. This shows a low level of cooperation between Russian companies and various stakeholders. In other words, the majority of surveyed firms rely more on their own capabilities and ideas, not using external sources of innovation. On average, in $45 \%$ of firms, employees were involved in training programs, which is a positive indicator for innovations. As for the management indicators, the years of experience of a top manager in the industry was, on average, almost 16 years, with a maximum of 60 years, which is a great experience. On average, nearly a third of the firms surveyed introduced new management practices.

The distribution of average indicators of management and innovative sales by industries (Figure 2) shows that, in general, high average values on all indicators belong to industries such as Office machinery, Basic metals, Chemicals, Communication equipment, Electronics, IT, etc. According to Hatzichronoglou (1997), these industries can be classified as medium- and high-tech industries. Low average values for these indicators are observed 
in Wood, Textiles, Paper \& paper products. The latter, according to Hatzichronoglou (1997), are low-tech industries.

Figure 2 | Distribution of average indicators of management and innovative sales by industries

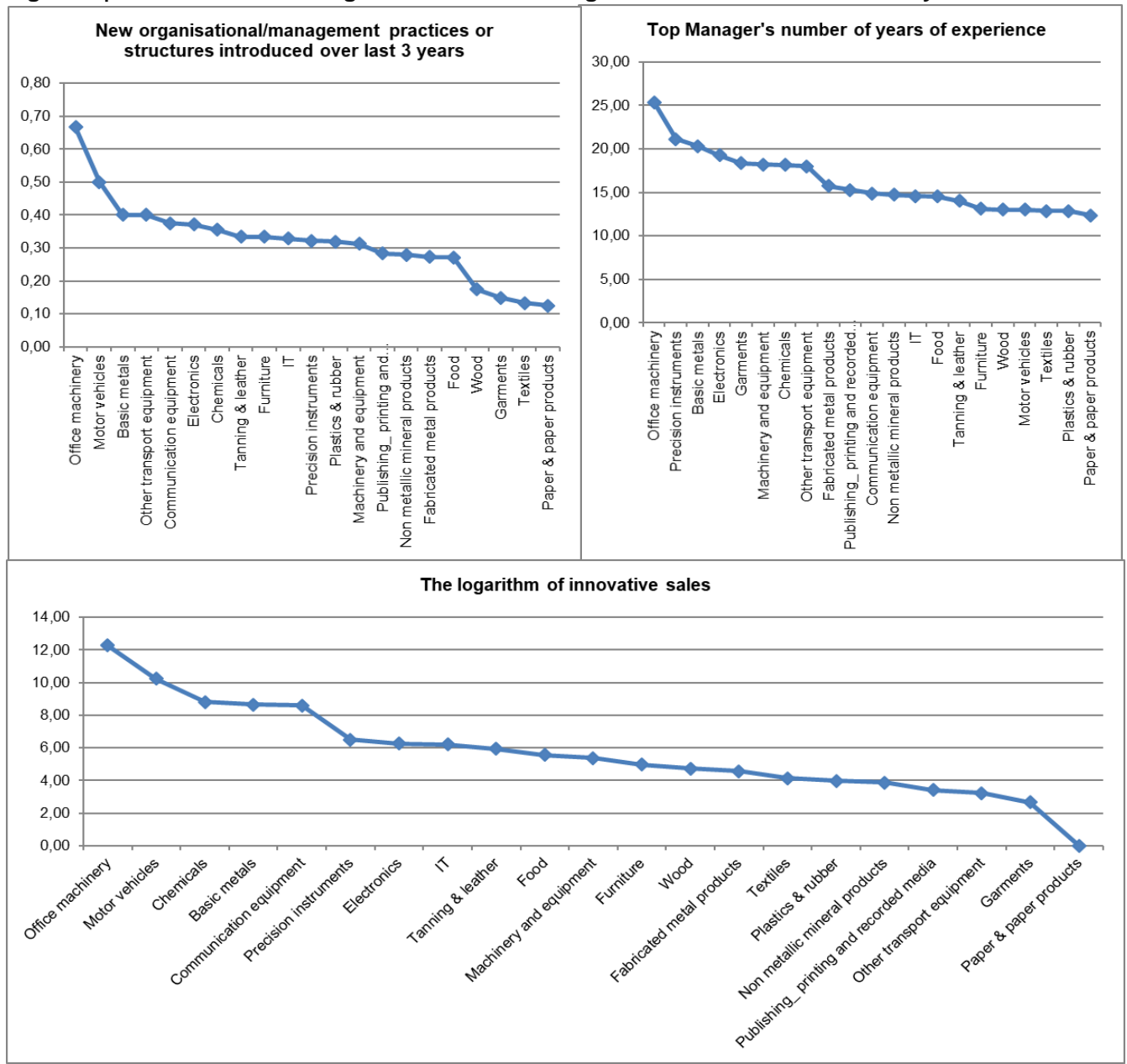

Source: authors' elaboration based on BEEPS 2012-2014

In other words, we can conclude that, in general, in those industries, where new managerial practices were most often implemented and top managers were experienced, innovative sales were higher.

It is also worth noting that all the equations contain regional and industrial dummy variables as their specific features are expected to be important for the innovation process and its results. The next section is devoted to results. 


\section{Results}

The $1^{\text {st }}$ step of the CDM model captures the probability of a firm's investments in research and development during the past three years. Results are presented in Table 3.

Table 3 | CDM model: the first stage

\begin{tabular}{|c|c|}
\hline $\begin{array}{l}\text { Dependent variable - the probability of investing in R\&D over } \\
\text { three years }\end{array}$ & All firms \\
\hline Size & $0.3177^{\star *}$ \\
\hline Age & -0.0016 \\
\hline Competition & -0.0007 \\
\hline Part of a larger enterprise & $0.2609^{*}$ \\
\hline Subsidies & $0.3591^{\star *}$ \\
\hline Taxes & $0.2150^{\star *}$ \\
\hline Inadequacy of employees' specialization & $0.2681^{\star \star *}$ \\
\hline Import & $0.5038^{* * *}$ \\
\hline Business licensing and permits & $0.2393^{* *}$ \\
\hline Regional innovation development index & $30.9810^{\star *}$ \\
\hline Industry dummies & Yes \\
\hline Regional dummies & Yes \\
\hline Wald test & $232.07^{\star \star *}$ \\
\hline Pseudo $\mathbf{R}^{2}$ & 0.16 \\
\hline Number of observations & 1475 \\
\hline
\end{tabular}

${ }^{\star * *}$ significant at the $1 \%$ level, ${ }^{* *}$ - at the $5 \%$ level, ${ }^{*}-$ at the $10 \%$ level.

Source: authors' elaboration based on BEEPS 2012-2014

The table shows that large firms are more likely to carry out R\&D. A possible explanation is that they have sufficient resources needed for this. Age turned out to be insignificant, so we can conclude that firms need to innovate in order to survive, and therefore age does not matter. Although competition should be a powerful mechanism for innovation, the number of competitors has an insignificant negative coefficient. This indicates a weak competitive environment and low innovative activity of firms in Russia.

Businesses belonging to a larger enterprise are also more likely to be involved in R\&D. This probably happens because of additional resources available within a larger enterprise, such as information, technologies and financial opportunities. Subsidies were found to have a positive impact on R\&D activities. This confirms the special importance of subsidies received from any sources for firms, especially for startups and small firms. Nonetheless, the problem of low awareness of funding programs remains. Some enterprises may not have access to government programs due to lack of information or other reasons. Importers are more inclined to perform $R \& D$. This may be explained by the availability of technologies and information that they obtain while working with foreign firms. 
Obstacles to current operations of firms, such as taxes, the inadequacy of the workers' specialization and business licensing and permits, have a significant positive impact on investment in R\&D. This shows that barriers arising from the institutional environment have a larger impact on the enterprises investing in $R \& D$.

Innovations in a region are found to influence positively firm's involvement in research and development.

In Table 4 there are results of the second step of the CDM model with two management indicators.

Table 4 | CDM model: second stage

\begin{tabular}{|c|c|c|}
\hline $\begin{array}{l}\text { Dependent variable - the logarithm of } \\
\text { innovative sales }\end{array}$ & $\begin{array}{l}\text { Top manager's experience } \\
\text { in the sector (years) }\end{array}$ & $\begin{array}{c}\text { New } \\
\text { organizational/management } \\
\text { practices or structures } \\
\text { introduced during past } 3 \\
\text { years (dummy-variable) }\end{array}$ \\
\hline $\begin{array}{l}\text { Predicted probability of investing in } \\
R \& D \text { over } 3 \text { years }\end{array}$ & $8.7971^{* \star *}$ & $7.8036^{* * *}$ \\
\hline Management indicator & $0.0467^{* * *}$ & $2.7931^{* \star *}$ \\
\hline Licensing & $3.8738^{*}$ & $4.0677^{\star *}$ \\
\hline Domestic suppliers & $7.9526^{* * *}$ & $7.7033^{* * *}$ \\
\hline Foreign suppliers & $5.5315^{\star * *}$ & $4.9801^{* * *}$ \\
\hline Domestic consumers & $9.4311^{* * *}$ & $8.9150^{\star \star \star}$ \\
\hline Foreign consumers & $9.8031^{* * *}$ & $8.1271^{\star * \star}$ \\
\hline Cooperation with universities & $6.0825^{\star \star \star}$ & $5.2896^{* *}$ \\
\hline Training of personnel & $1.0849^{* * *}$ & $0.6326^{*}$ \\
\hline Industry dummies & Yes & Yes \\
\hline Regional dummies & Yes & Yes \\
\hline R-squared & 0.25 & 0.28 \\
\hline F-test & $12.39^{\star \star \star *}$ & $12.54^{\star \star \star}$ \\
\hline Number of observations & 1448 & 1477 \\
\hline
\end{tabular}

${ }^{* * *}$ significant at the $1 \%$ level, ${ }^{* *}$ - at the $5 \%$ level, ${ }^{*}$ - at the $10 \%$ level.

Source: authors' elaboration based on BEEPS 2012-2014

The results of the second stage of the model show a positively significant return on investment in research and development as an integral part of the innovation process. Interaction with different organizations (through licensing, cooperation with suppliers, customers and universities) facilitate innovative sales. It implies that exchange of knowledge can be useful for various types of innovations. Bartz et al. (2016) suggest a similar idea about foreign owners being a source of information concerning innovations. Training of personnel, an indicator of the firm's human capital, positively affects the 
innovative result. For firms, training is especially important to keep up with the on-going innovations of their competitors.

Management indicators, such as the experience of a top manager and the introduction of new management practices during the past three years, positively influence sales of new products. Moreover, the second indicator quantitatively produces a greater effect on the innovative result. This suggests that the quality of management is an equally important factor affecting the commercialization of new products as an investment in R\&D. In particular, management practices include many elements - from monitoring the achievement of target production indicators to developing a bonus system and promoting employees. Such practices, of course, shape the results of a company's innovative activities. Besides, according to the literature, the experience in the same industry improves innovative results, especially under less favourable institutional conditions (Bartz et al., 2016).

Now we turn to a discussion of the $3^{\text {rd }}$ step of the CDM model (Table 5).

Table 5 | CDM model: third stage

\begin{tabular}{lcc}
\hline $\begin{array}{l}\text { Dependent variable - the } \\
\text { logarithm of labour productivity }\end{array}$ & $\begin{array}{c}\text { Top manager's } \\
\text { experience in the sector } \\
\text { (years) }\end{array}$ & $\begin{array}{c}\text { New } \\
\text { organizational/management } \\
\text { practices or structures }\end{array}$ \\
$\begin{array}{l}\text { Predicted Innovative sales per } \\
\text { employee }\end{array}$ & $0.0293^{*}$ & $\begin{array}{c}\text { introduced during the past three } \\
\text { years (dummy-variable) }\end{array}$ \\
\hline
\end{tabular}

\begin{tabular}{lll}
\hline Capital costs per employee & $1.2326^{\star \star *}$ & $1.2275^{\star * *}$ \\
\hline Labor costs per employee & $0.4059^{\star \star \star}$ & $0.4081^{\star \star *}$
\end{tabular}

\begin{tabular}{lcc}
\hline F-test & 0.44 & 0.44 \\
\hline Number of observations & 359 & 359
\end{tabular}

*** significant at the $1 \%$ level, ${ }^{* *}$ - at the $5 \%$ level, ${ }^{*}$ - at the $10 \%$ level.

Source: authors' elaboration based on BEEPS 2012-2014

Table 5 demonstrates the positive impact of innovations on labour productivity in both specifications of the model. Production factors also have a positive impact on enterprise productivity. In other words, renewal of fixed assets and higher wages lead to an increase in productivity. It is also worth noting that the industry and regional dummies are both significant at all stages of the model reflecting specific features of industries and regions.

\section{Conclusion}

As innovations are acknowledged to be drivers of productivity, they are of interest for policymakers. Management practices deserve attention as well as being at the core of the firms' success. Therefore in this paper, we focus our attention on management quality among the other factors affecting firms' innovation and productivity.

In the countries with the less favourable institutional environment, it is relatively more difficult for the firms to engage in innovations. Moreover, it is relatively easier to improve management practices than to get involved in independent R\&D or start cooperation with 
various stakeholders, potentially leading to innovation. Therefore it is especially important to improve management practices, in order both to improve performance and to be able to innovate in the existing institutional environment (Bartz et al., 2016).

The results of our econometric analysis show that innovations bring firms productivity gains and that the impact of management on innovations is substantial. Our research contributes to the understanding of the importance of management quality in the firms' innovative activities among the other internal and external factors affecting innovations.

Results show that large firms and firms belonging to a large enterprise are more likely to carry out R\&D. For larger firms, it is probably easier to provide substantial financing needed for R\&D. Besides, such firms can use information and technologies within the enterprise. Moreover, larger firms and firms belonging to a large enterprise might be more stable in the existing institutional environment. The competition turned out not to stimulate R\&D, probably due to a weak competitive environment in Russia. The importance of subsidies received from any sources was confirmed. Subsidies are especially important for startups and small firms as they have lack of resources for R\&D. Therefore it is essential to provide such a source of financing and to inform firms about this.

It was found that firms involved in the import are more inclined to invest in R\&D. These firms probably receive access to technologies and knowledge concerning the product, process, organizational structure or approach to marketing that foreign firms possess and therefore are more likely to carry out innovations in some of these aspects of their work. Firms involved in innovative activities were found to be more affected by the business environment than the others. In particular, the inadequacy of the workers' specialization indicates the dissatisfaction of firms with the qualifications of workers, and business licensing and permits indicates the complexity of bureaucratic procedures for obtaining any permission. Innovative development on the regional level proved to influence enterpriselevel $R \& D$ in a positive way.

Further, we found a significant positive return on investment in R\&D. Cooperation with various stakeholders was found to contribute to an increase in sales of new products. This indicates the usefulness of collaborating with other stakeholders on innovation, as such interaction is a valuable source of information needed for the innovation process. Training of personnel as an indicator of a firm's human capital positively affects the innovative result. This outcome demonstrates the importance of introducing employee training programs on a regular basis in order to quickly adapt to changing market trends. Management quality indicators, the experience of a top manager and new management practices during the past three years, positively influence innovation results, the second indicator being more important.

Concerning the impact of innovation on firms' labour productivity, results show significant returns on innovations; renewal of fixed assets and higher wages also lead to an increase in productivity.

Overall, results show that the firms' R\&D expenditures result in successful commercialization and positively affect productivity, while management quality plays an important role in this process. It emphasizes the importance of R\&D for the firms and brings attention to creating an environment favourable for innovation activity. Institutions should provide economic freedom for innovative activities. The same time, state support in the 
areas such as providing more accessible financing through subsidies is important. Besides, high educational standards, as well as basic and applied research, that are essential for innovations require a reasonably designed state intervention. Various forms of cooperation with stakeholders, national and foreign, proved to be favourable for innovations as well. This finding supports the ideas of facilitating cooperation and cluster policy, where it is relevant. The quality of management was found to be a factor important for companies' innovative activities, more specifically, for the commercialization of new products. Particularly, for the owners of the companies, it is worth paying attention to the experience of the top managers in their specific field, while the introduction of new organizational and management practices or structures substantially contributes to innovations and productivity and deserves attention as well.

Results can be applied by the enterprises interested in innovations and by policymakers involved in facilitating innovations at the regional and country level.

\section{Acknowledgement}

Research was supported by the grant of the Russian Science Foundation № 19-18-00262 "Empirical modelling of balanced technological and socioeconomic development in the Russian regions".

\section{References}

Bartz, W., Mohnen, P. \& Schweiger, H. (2016). The role of innovation and management practices in determining firm productivity in developing economies. UNU-MERIT working papers, 2016-034, $1-45$.

Bozic, L., \& Botric, V. (2011). Innovation Propensity in the EU Candidate Countries. Innovation, knowledge, research papers, 18, 405-417. https://doi.org/10.1007/S11300-011-0205-3.

Business Environment and Enterprise Performance Survey - BEEPS. (2012-2014). Enterprise Survey. Retrieved February 02, 2017, from ebrd-beeps.com.

Cirera, X. (2015). Catching up to the technological frontier? Understanding firm-level innovation and productivity in Kenya. Innovation and Entrepreneurship, Trade and Competitiveness Global Practice, the World Bank, 94671, 1-45.

Crépon, B., Duguet, E., \& Mairesse, J. (1998). Research Investment, Innovation and Productivity: an Econometric Analysis. Economics of Innovation and New Technology, 7, 115-158. https://doi.org/10.1080/10438599800000031.

Dabla-Norris, E., Kersting, E. K., \& Verdier, G. (2012). Firm productivity, innovation, and financial development. Southern Economic Journal, 79(2), 422-449. https://doi.org//10.4284/0038-40382011.201.

Griliches, Z. (1986). Productivity, R\&D and Basic Research at the Firm Level in the 1970s. American Economic Review, 76(1), 143-154. Stable URL: https://www.jstor.org/stable/1804132.

Grossman, G. \& Helpman, E. (1994). Endogenous Innovation in the Theory of Growth. The Journal of Economic Perspectives, (8)1, 23-44. http://dx.doi.org/10.1257/jep.8.1.23.

Dvouletý, O., \& Blažková, I. (2019). The Impact of Public Grants on Firm-Level Productivity: Findings from the Czech Food Industry. Sustainability, 11(2), 552. https://doi.org/10.3390/su11020552. 
Duguet, E. (2006). Innovation height, spillovers and TFP growth at the firm level: Evidence from French manufacturing. Economics of Innovation and New technology, 15(4-5), 415-442. https://doi.org/10.1080/10438590500512968.

Hall, B. H., Lotti, F., \& Mairesse, J. (2008). Employment, innovation, and productivity: evidence from Italian microdata. Industrial and Corporate Change, 17(4), 813-839. https://doi.org/10.1093/icc/dtn022.

Hashi, I., \& Stojcic, N. (2012). The impact of innovation activities on firm performance using a multistage model: Evidence from the Community Innovation Survey 4. Research Policy, 42(2), 353366. https://doi.org/10.15179/ces.16.2.5.

Hatzichronoglou, T. (1997). Revision of the High-Technology Sector and Product Classification. OECD Science, Technology and Industry Working Papers, 2, 1-25.

Janz, N., Lööf, H., \& Peters, B. (2003). Firm level innovation and productivity-is there a common story across countries? ZEW Discussion Papers, 03-26, 1-35.

Koudelková, P. (2014). Innovation in small and medium enterprises in the Czech Republic. Central European Business Review, 3(3), 31-37. https://doi.org/10.18267/j.cebr.91.

Lööf, H., \& Heshmati, A. (2003). The link between firm-level innovation and aggregate productivity growth: a cross-country examination. Research evaluation, 1(2), 131-147.

Marotta, D., Mark, M., Blom, A., \& Thorn, K. (2007). Human Capital and University-Industry linkages' role in fostering firm innovation: an empirical study of Chile and Colombia. The World Bank, WPS4443, 1-41.

Mohnen, P. \& Hall, B. H. (2013). Innovation and productivity: an update. Eurasian Business Review, 3(1), 47-65.

Nelson, R. \& Winter, S. (1982). An Evolutionary Theory of Economic Change. Cambridge: Harvard University Press.

OECD \& Eurostat. (2005). Oslo Manual: Guidelines for Collecting and Interpreting Innovation Data, 3rd Edition, The Measurement of Scientific and Technological Activities. OECD Publishing, Paris, https://doi.org/10.1787/9789264013100-en.

Petrin, A., Poi, B. P., \& Levinsohn, J. (2004). Production function estimation in Stata using inputs to control for unobservables. The Stata Journal, 4(2), 113-123.

Porter, M. (1998). On Competition. Boston; Toronto; London: Harvard Business Review Book.

Potluka, O. \& Dvouletý, O. (2018). Enhancement of innovations through the public programmes: Does it work? Public Policy Portuguese Journal, 3(1), 75-85.

Prędkiewicz, K. (2017). Attitude towards innovation and barriers in capital access. Central European Business Review, 6(2), 64-76.

Romer, P. (1990). Endogenous Technological Change. The Journal of Political Economy, 98(5), S71S10.

Schumpeter, J. A. (1934). The Theory of Economic Development: An Inquiry into Profits, Capital, Credit, Interest, and the Business Cycle. Cambridge: Harvard University Press.

Solow, R. (1957). Technical Change and the Aggregate Production Function. The Review of Economics and Statistics, 39(3), 312-320.

Teplykh, G. V. (2018). Innovations and productivity: the shift during the 2008 crisis. Industry and Innovation, 25(1), 53-83. https://doi.org/10.1080/13662716.2017.1286461. 
Zemtsov S., Muradov A., Wade I. \& Barinova V. (2016). Determinants of Regional Innovation in Russia: Are People or Capital More Important? Foresight and STI Governance, 10(2), pp. 29-42. https://doi.org/10.17323/1995-459X.2016.2.29.42.

Zhukov, A. N., Nagieva, K. M. K., \& Shorokhova, I. S. (2017). Vliyanie innovatsionnoy aktivnosti v rossiyskikh regionakh na deyatel'nost' predpriyatiy (Influence of innovation activity in the Russian regions on enterprise performance). Zhurnal Ekonomitcheskoy teorii (Journal of Economic Theory), 3, 153-157.

The research paper passed the review process. | Received: January 16, 2020; Revised: January 24, 2020; Accepted: March 6, 2020; Published: July 10, 2020 